(C) The Author(s), 2021. Published by Cambridge University Press on behalf of the University of Arizona. This is an Open Access article, distributed under the terms of the Creative Commons Attribution licence (http://creativecommons.org/licenses/by/4.0/), which permits unrestricted re-use, distribution, and reproduction in any medium, provided the original work is properly cited.

\title{
RADIOCARBON, TRACE ELEMENTS AND PB ISOTOPE COMPOSITION OF PINE NEEDLES FROM A HIGHLY INDUSTRIALIZED REGION IN SOUTHERN POLAND
}

\author{
Barbara Sensuła $^{1 *}$ (D) Nathalie Fagel $^{2}$ - Adam Michczyński ${ }^{1}$ \\ ${ }^{1}$ The Silesian University of Technology, Institute of Physics - Center for Science and Education, Konarskiego 22B, \\ Gliwice 44-100, Poland \\ ${ }^{2}$ Université de Liège, Département de Géologie, UR AGEs - Argiles, Géochimie et Environnement sédimentaires, \\ Quartier Agora, Allée du six Août 14, B-4000 Liege, Belgium
}

\begin{abstract}
We determined the chemical composition of pine needles to monitor environmental contamination in an urban forest environment in the most industrialized part of southern Poland. The concentrations of radiocarbon $\left({ }^{14} \mathrm{C}\right)$, trace elements $(\mathrm{Cr}, \mathrm{Co}, \mathrm{Ni}, \mathrm{Cu}, \mathrm{Zn}, \mathrm{Rb}, \mathrm{Sr}, \mathrm{Ba}, \mathrm{Ce}, \mathrm{Pb})$ and the $\mathrm{Pb}$ isotope composition were measured in needles from Pinus sylvestris L. growing in nine urban forests near five factories. The investigated young pine needles were collected in January 2013 and September 2013, respectively. ${ }^{14} \mathrm{C}$ concentration was determined by liquid scintillation counter, trace elemental concentration and $\mathrm{Pb}$ isotope ratio were determined by ICP-MS and MC-ICP-MS, respectively. Analysis of trace metal pollution is based on the assumption that element concentrations in tree foliage represent element availability in the environment. Different space-time patterns of element accumulation in pine needles were observed. The variation in isotopic composition reflects a mix between different anthropogenic sources.
\end{abstract}

KEYWORDS: contemporary pollution, $\mathrm{Pb}$ isotopes, pine foliage, radiocarbon, trace elements.

\section{INTRODUCTION}

Human activities resulting in the emission of different pollutants to the atmosphere affect the physiological processes that control tree growth. The determination of tree-ring and foliage properties is crucial in the investigation of local and global environmental changes. Treering analysis and the determination of the chemical composition of wood and foliage are useful in ecosystem biomonitoring, in particular when assessing the impacts of soil, air, and water pollution (e.g., Kabata-Pendias and Pendias 1992; Rovinsky et al. 1993; Dmuchowski and Bytneroicz 1995; Adriano 2001; Pomierny and Ciepał 2004; Prasad et al. 2006; Jelaska 2007; Savard 2010; Malik et al. 2012; Przybysz et al. 2014; Sensuła et al. 2017). In this context, the monitoring of trace heavy metals is important, and based on the elemental and isotopic composition of pine needles as well as tree-ring analysis, we can identify the sources of air contamination (Lukaszewski et al. 1988; Kabata-Pendias and Pendias 1992; Rovinsky et al. 1993; Alfanie et al. 1996; Adriano 2001; Prasad et al. 2006; Jelaska 2007; Savard 2010; Pazdur et al. 2013; Przybysz et al. 2014; Sensuła 2015, 2016). Environmental biomonitoring can be used to measure the cumulative impact of different types of environmental pressures, including air contaminants emitted from different sources as well as soil and water contamination.

Scots pine (Pinus sylvestris) needles have widely been used as bioindicators for reforestation success in post-mining areas in central Europe, mainly because this species can survive on acidic and dry soils (Białobok 1976; Dmuchowski and Bytnerowicz 1995; Baumann et al. 2006; Kuznetsova et al. 2010). Most heavy metals are derived from anthropogenic sources, such as different industrial activities (e.g., metal refining, waste incineration, burning of coal and wood, coal and petroleum combustion, mining, metallurgy and metal smelting, barning of waste, and cement production), private householders, and motor vehicles. The contamination of air, rain, and soil can be a source of foliar injury. Geochemical analyses

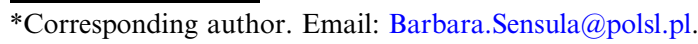


of Scots pine (Pinus sylvestris L.) needles have been performed previously (Dmuchowski and Bytnerowicz 1995), because this species is able to survive and grow on reclaimed mine soil (Białobok 1976; Pietrzykowski et al. 2014).

Plants can take up nutrients via the roots or the stomata. The stomata facilitate active exchange between leaf and atmosphere, representing the active interface between plants and their atmospheric environment. The local carbon cycle is very important to understand biological and chemical process and different interaction in the environment. Human activities over the past two hundred years have significantly increased the amount of carbon in the atmosphere, by emitting it directly (e.g., by fossil fuel combustion) or by changing ecosystems' ability to extract $\mathrm{CO}_{2}$ from the atmosphere (e.g., by deforestation). Not only carbon concentration, but also the carbon isotopic composition of the Earth's atmosphere has been modified by human activities. Fossil fuels combustion have also diluted the ${ }^{14} \mathrm{CO}_{2}$ in the air (Suess effect, Keeling 1979). Human nuclear activities (connected with nuclear tests, nuclear power plant) increase anthropogenic ${ }^{14} \mathrm{CO}_{2}$ in the air. The analysis of contemporary samples of pine needles and tree rings growing in different sampling sites around three industrial factories in Silesia (Sensuła et al. 2018), shown high concentration of radiocarbon $\left({ }^{14} \mathrm{C}\right)$.

Elements taken up from the soil via roots can be accumulated in roots and leaves. While some elements taken up by plants are essential for growth and development, some are toxic (KabataPendias and Pendias 1992). The most toxic metals for higher plants are $\mathrm{Hg}, \mathrm{Cu}, \mathrm{Ni}, \mathrm{Pb}, \mathrm{Co}, \mathrm{Cd}$, and possibly Ag, Be, and $\mathrm{Sn}$. The assessment of toxic concentrations and effects of trace elements on plants is highly complex because it depends on several factors that cannot be measured on a linear scale (Kabata-Pendias and Pendias 1992). Elements taken up by plants from the atmosphere can provide clues about air pollution, whereas elements taken up via the roots can provide information about past contamination, as some elements can remain in the soil over several years. For example, $\mathrm{Pb}$ is mainly derived from anthropogenic sources (De Vleeschouwer et al. 2007, 2009) and can remain in the soil for thousands of years. The concentration of the elements in soil and air is area-specific. For instance, Steinnes et al. (2005) measured the highest concentrations of lead in the surface layer of soils in southern Poland $(\leq 142 \mathrm{mg} / \mathrm{kg})$. The following threshold concentrations have been established for soils of coniferous forest sites in southern Poland: copper $(150 \mathrm{mg} / \mathrm{kg})$, zinc $(500 \mathrm{mg} / \mathrm{kg})$, and lead $(1500 \mathrm{mg} / \mathrm{kg})$ (Zwoliński 1995); these elements are largely linked to industrial emissions in the area.

In Silesia, southwestern Poland, high levels of pollution were recorded from 1960 to 1990 , mainly caused by the industrial sector. Trees respond differently to environmental stress, e.g., by decreased growth, increased heterogeneity of tree-ring growth, reduced sensitivity to short-term environmental impulses, and changes in wood composition. After a significant reduction in pollution loads in the early 1990s, pines quickly recovered (Sensuła et al. 2015a, 2015b, 2017). Different investigations have been conducted in Silesia, mainly near factories, to assess the impacts of anthropogenically caused contamination on pine tree stands (for example, Norman 1999; Malik et al. 2012; Sensuła 2016; Sensuła et al. 2017). In such investigations, the determination of the chemical properties of tree rings and foliage is crucial to evaluate environmental changes. In particular, the monitoring of heavy metals stands out, as they not only impact plant growth and development, but also human health.

In this context, we used trace metal and $\mathrm{Pb}$ isotopes measured in pine needles as bioindicators of the accumulation of elements emitted into the atmosphere and deposited in foliage, focusing on $\mathrm{Cr}, \mathrm{Co}, \mathrm{Ni}, \mathrm{Cu}, \mathrm{Zn}$, and $\mathrm{Pb}$ in young needles. 


\section{MATERIAL AND METHODS}

Pine needles (Pinus sylvestris L.) from the current year were collected from forests located at different distances from factories (Figure 1, Table 1) within nine communes or cities in the highly populated and industrialized southern part of Poland.

Three sampling sites were located in Opole Province near the Petrochemia-Blachownia chemical factory (BL) and a nitrogen factory (KK, ancient name: Zakłady Azotowe Kędzierzyn-Koźle), on the highway A4 within the communes of Sławięcice $\left(50^{\circ} 20^{\prime} 15.7^{\prime \prime} \mathrm{N}\right.$; $18^{\circ} 19^{\prime} 52^{\prime \prime} \mathrm{E}$, site 1), Rudziniec $\left(50^{\circ} 20^{\prime} 3.6^{\prime \prime} \mathrm{N} ; 18^{\circ} 24^{\prime} 29.9^{\prime \prime} \mathrm{E}\right.$, site 2 ), and Rudno (50 $21^{\prime} 26.4^{\prime \prime} \mathrm{N} ; 18^{\circ} 28^{\prime} 14.5^{\prime \prime} \mathrm{E}$, site 3). The other six sampling sites were located in the province of Silesia. Of these, six were near the Laziska Power Plant (LA) in the communes of Wyry $\left(50^{\circ} 9^{\prime} 38.8^{\prime \prime} \mathrm{N} ; 18^{\circ} 56^{\prime} 4.4^{\prime \prime} \mathrm{E}\right.$, site 4), Mikołów $\left(50^{\circ} 10^{\prime} 35.1^{\prime \prime} \mathrm{N} ; 18^{\circ} 58^{\prime} 52.8^{\prime \prime} \mathrm{E}\right.$, site 5), and Podlesie $\left(50^{\circ} 8^{\prime} 55.4^{\prime \prime} \mathrm{N} ; 18^{\circ} 53^{\prime} 4.9^{\prime \prime} \mathrm{E}\right.$, site 6$)$, while three were near a coking plant (KO) and a steel factory (HK, Huta Katowice/ArcelorMittal Poland Oddział) in Dąbrowa Górnicza, in the communes of Dąbrowa Górnicza $\left(50^{\circ} 21^{\prime} 48.5^{\prime \prime} \mathrm{N} ; 19^{\circ} 19^{\prime} 24^{\prime \prime} \mathrm{E}\right.$, site 7), Lazy (50 $24^{\prime} 58.4^{\prime \prime} \mathrm{N} ; 1^{\circ} 22^{\prime} 56.8^{\prime \prime} \mathrm{E}$, site 8) and Ogrodzieniec $\left(50^{\circ} 26^{\prime} 27^{\prime \prime} \mathrm{N} ; 1^{\circ} 29^{\prime} 30.6^{\prime \prime} \mathrm{E}\right.$, site 9). According to the environmental reports of Chief Inspector of Environmental Protection (http://www.gios.gov.pl/), these factories were listed as some of the most polluting factories up to the late 1990s. Nowadays, air contamination due to industrial emissions is not as significant as it was in 20th century, but emissions from transport and domestic coal burning are still a matter of concern.

The sampling sites were selected to be in the direction of the dominant winds. In January 2013, we sampled young pine needles formed in 2012 (sample numbers 1-9, collected from sites 1-9). The samples were collected on the same day to avoid weather influences. In addition, needles were also collected in 2013 for three of the sampling sites. The needles formed in 2013 were collected in September 2013 (sample numbers 10-12, collected from sites 4, 5, and 6, respectively).

Needles were collected from the tree crowns, placed in plastic bags, and separated manually in the laboratory. Prior to geochemical analysis, samples were lyophilized. For ${ }^{14} \mathrm{C}$ analysis and fraction modern determination $\left({ }^{14} \mathrm{~F}\right)$, the needles were prepared using a standard acid-alkaliacid treatment in a three-step treatment: (1) $2 \% \mathrm{HCl}$ at $80^{\circ} \mathrm{C}$ for $2 \mathrm{hr}$, neutralization with deionized water, (2) $2 \mathrm{~N} \mathrm{NaOH}$ at $80^{\circ} \mathrm{C}$ for $2 \mathrm{hr}$, neutralization with deionized water, (3) $2 \% \mathrm{HCl}$ at $80^{\circ} \mathrm{C}$ for $2 \mathrm{hr}$, neutralization with deionized water and dried, then washed with distilled water to neutral $\mathrm{pH}$, thus $\mathrm{NaOH}$, samples were converted to benzene for LSC (liquid scintillation counter) measurements. Measurement of $\left({ }^{14} \mathrm{C}\right)$ concentrations in pine needles was performed with a $\beta$-radiation liquid spectrometer of the Quantulus 1220 type (Pazdur et al. 2013). The background $\mathrm{F}^{14} \mathrm{C}$ was equal to $0.019 \mathrm{pMC}$. The reference material ANU Sucrose (Rozanski 1991) was used and the fraction modern was calculated according to Mook and van der Plicht (1999).

For ICP-MS and MC-ICP-MS analyses, the samples were first dried at $90^{\circ} \mathrm{C}$ for $24 \mathrm{hr}$, manually ground into a powder, and combusted at $550^{\circ} \mathrm{C}$ for $4 \mathrm{hr}$ to remove organic matter. Combusted samples were transferred to Teflon vials and digested via two steps: (1) a mixture of $4 \mathrm{~mL}$ of $\mathrm{HF} 36 \mathrm{~N}$ and $1 \mathrm{~mL}$ of $\mathrm{HNO}_{3} 14 \mathrm{~N}$ was added, and the samples were kept at $120^{\circ} \mathrm{C}$ for $48 \mathrm{hr}$; (2) $\mathrm{HCl} 6 \mathrm{~N}$ was added, and the samples were kept at $140^{\circ} \mathrm{C}$ for 48 hr. Each step was followed by evaporation at $90^{\circ} \mathrm{C}$. Subsequently, the samples were dissolved in $1 \mathrm{~mL}$ of $5 \% \mathrm{HNO}_{3}$ and divided into two parts. The first part, i.e., $200 \mu \mathrm{L}$ of 
Table 1 Sampling sites.

\begin{tabular}{|c|c|c|c|}
\hline No. & $\begin{array}{l}\text { Sampling site } \\
\text { commune }\end{array}$ & Lab code & Localization, distance from factories \\
\hline 1 & Sławięcice & KK_5 & $\begin{array}{l}6.5 \text { from a nitrogen factory, } 3 \mathrm{~km} \text { from the } \\
\text { chemical factories Petrochemia-Blachownia }\end{array}$ \\
\hline 2 & Rudziniec & KK_10 & $\begin{array}{l}11 \text { from a nitrogen factory, } 7 \mathrm{~km} \text { from } \\
\text { Petrochemia-Blachownia }\end{array}$ \\
\hline 3 & Rudno & KK_15 & $\begin{array}{l}16 \text { from a nitrogen factory, } 10 \mathrm{~km} \text { from } \\
\text { Petrochemia-Blachownia, and ca. } 1-2 \mathrm{~km} \\
\text { from the highway }\end{array}$ \\
\hline 4 & Wyry & LA_5 & $\begin{array}{l}3 \mathrm{~km} \text { from } \text { Laziska, a combined heat and } \\
\text { power plant, and } 3 \mathrm{~km} \text { from the local road }\end{array}$ \\
\hline 5 & Mikołów & LA_10 & $\begin{array}{l}7 \mathrm{~km} \text { from Laziska and } 2 \mathrm{~km} \text { from the local } \\
\text { road }\end{array}$ \\
\hline 6 & Podlesie & LA_15 & $10 \mathrm{~km}$ from Łaziska \\
\hline 7 & Dąbrowa Górnicza & HK_5 & $\begin{array}{l}3 \mathrm{~km} \text { from the steel factory Huta Katowice } \\
\text { and a coking plant }\end{array}$ \\
\hline 8 & Łazy & HK_10 & $\begin{array}{l}11 \mathrm{~km} \text { from the steel factory Huta Katowice } \\
\text { and a coking plant }\end{array}$ \\
\hline 9 & Ogrodzieniec & HK_15 & $\begin{array}{l}19 \mathrm{~km} \text { from the steel factory Huta Katowice } \\
\text { and a coking plant; close to a local road }\end{array}$ \\
\hline
\end{tabular}

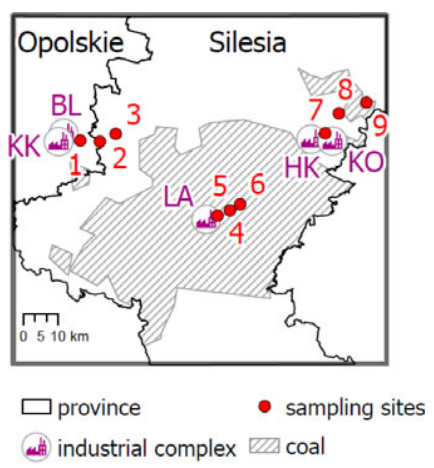

Figure 1 Location of nine sampling sites near different factories (BL-Petrochemia-Blachownia and KK-nitrogen factories in Kędzierzyn Koźle, LA-power plant in Laziska, KO-coking plant and HK-steel factory in Dąbrowa Górnicza) in the provinces of Opolskie and Silesia. The coal basin is indicated on the map (geoportal.pgi.gov.pl: http://geoportal.pgi.gov.pl/css/surowce/images/2012/mapy/large/large_8.jpg).

the solution, was transferred into a Teflon vial for elemental analysis and then evaporated to dryness at $90^{\circ} \mathrm{C}$. The second part, corresponding to $800 \mu \mathrm{L}$ of the solution, was used for lead isotope analysis. This part was evaporated at $90^{\circ} \mathrm{C}$, and the dried residue was dissolved in $500 \mu \mathrm{L}$ of $\mathrm{HBr} 0.8 \mathrm{~N}$ prior to chromatographic separation. Lead separation was made by using anion-exchange chromatography by successive adding of $\mathrm{HBr}$ and $\mathrm{HCl}$ in the clean class-100 laboratory at the University of Liège (Belgium) (De Vleeschouwer et al. 2007). The eluted $\mathrm{Pb}$ solution was evaporated and stored prior to analysis. 
Before the analysis, the ICP-MS instrument was calibrated and linearity was checked for the BHVO2 standard concentrations of $0,0.01,0.1,5,10$, and $20 \mathrm{ppb}$. Repeated blank measurements were used to determine the limit of detection for each element. Replicates (i.e., run of the same samples twice) and duplicate (i.e., repetition of the analyses with different aliquots of the same samples) were performed. The standard deviation of each result was $\leq 5 \%$.

Lead isotopes (Table 3) were measured using the $\mathrm{Nu}$ Instruments Multi-Collector Inductively Coupled Plasma Mass Spectrometer (MC-ICP-MS) at the Laboratoire G-Time (Université Libre de Bruxelles, Belgium). For MC-ICP-MS, the standard NBS981 was repeatedly measured in alternation with samples to control any daily instrument drifts.

\section{RESULTS AND DISCUSSION}

The spatial and temporal variations of the element levels $(\mathrm{Cr}, \mathrm{Co}, \mathrm{Ni}, \mathrm{Cu}, \mathrm{Zn}, \mathrm{Pb})$ are reported in Figures 2 and 3. The results of ${ }^{14} \mathrm{C}$ analysis and fraction modern determination and trace element concentrations in the pine needles from different sites are presented in the Table 2 . The needles were characterized based on the concentrations of $\mathrm{Cr}$, ranging from 0.05 to $0.7 \mathrm{mg} / \mathrm{kg}$, Co, from 0.005 to $0.075 \mathrm{mg} / \mathrm{kg}$, Ni, from 0.12 to $0.66 \mathrm{mg} / \mathrm{kg}, \mathrm{Cu}$, from 0.49 to $1.0 \mathrm{mg} / \mathrm{kg}, \mathrm{Zn}$, from 3.9 to $14 \mathrm{mg} / \mathrm{kg}$, and $\mathrm{Pb}$, from 0.06 to $0.53 \mathrm{mg} / \mathrm{kg}$. These values represent the minimum concentrations, as some contamination deposited on the needle surface may have been removed by precipitation or wind.

The spatial and temporal variations of the lead isotope ratios are shown in Figure 4 and Table 3. The range of $\mathrm{Pb}$ isotope ratios was relatively narrow. In the area near the chemical factories in Kędzierzyn-Koźle, ${ }^{206} \mathrm{~Pb} /{ }^{207} \mathrm{~Pb}$ isotope ratios ranged between 1.15 (KK_5) and 1.17 (KK_10), whereas ${ }^{208} \mathrm{~Pb} /{ }^{206} \mathrm{~Pb}$ varied between 2.09 (KK_10 and KK_15) and 2.11 (KK_5). Near the Power Plant in Laziska, ${ }^{206} \mathrm{~Pb} /{ }^{207} \mathrm{~Pb}$ isotope ratios ranged between 1.163 (LA_5 and LA_15) and 1.168 (LA_10), whereas ${ }^{208} \mathrm{~Pb} /{ }^{206} \mathrm{~Pb}$ varied between 2.093 (LA_10) and 2.097 (LA_15). Near the steel factory "Huta Katowice" in Dąbrowa Górnicza, ${ }^{206} \mathrm{~Pb} /{ }^{207} \mathrm{~Pb}$ isotope ratios ranged from 1.168 (KK_10) to 1.174 (HK_15) and ${ }^{208} \mathrm{~Pb} /{ }^{206} \mathrm{~Pb}$ from $2.082\left(\mathrm{HK} \_5\right)$ to $2.094\left(\mathrm{HK} \_15\right)$.

\section{Radiocarbon}

Plants convert $\mathrm{CO}_{2}$ from the air into cellulose and while living, plants are in equilibrium with their surroundings by exchanging carbon with the atmosphere. In the highly populated Silesia region, where a burning fossil fuels is the largest source of $\mathrm{CO}_{2}$ emission and which is located far from nuclear power plant, a Suess effect (Keeling 1979) a ${ }^{14} \mathrm{C}$ depletion in pine needles relative to clean air, was expected, we have found that higher concentration of ${ }^{14} \mathrm{C}$ in the needles relative to clean air. Review of the literature describes the pathway and associated fractionation of ${ }^{14} \mathrm{C}$ and $\delta^{13} \mathrm{C}$ in $\mathrm{CO}_{2}$ during photosynthesis, respiration and dissolution by groundwater (Białobok et al. 1993; Dawson et al. 2002; Trumbore 2006). The changes in carbon isotopes fractionation during these processes are smaller than differences in ${ }^{14} \mathrm{C}$ composition of the ${ }^{14} \mathrm{C}$ in current atmospheric background (Hammer and Levin 2017) in pine foliage in Silesia. We suppose that, in the region of Silesia localized far from nuclear power plant, that the observed enrichment in ${ }^{14} \mathrm{C}$ in pine needles can be connected with point-source emitters, where products enriched in ${ }^{14} \mathrm{C}$, are utilized and combusted (for example products used in ${ }^{14} \mathrm{C}$-labeling in medical sector, or probably also household wood burning). To confirm or to reject this hypothesis, additional analyses will be done in future. 

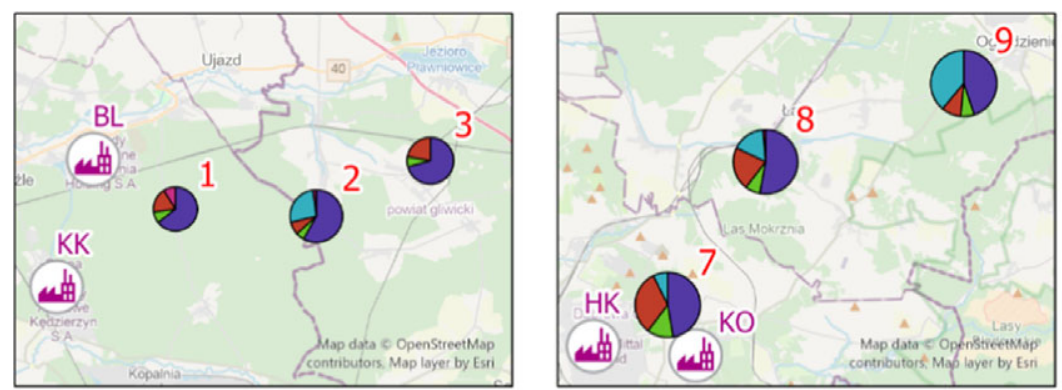

Elements
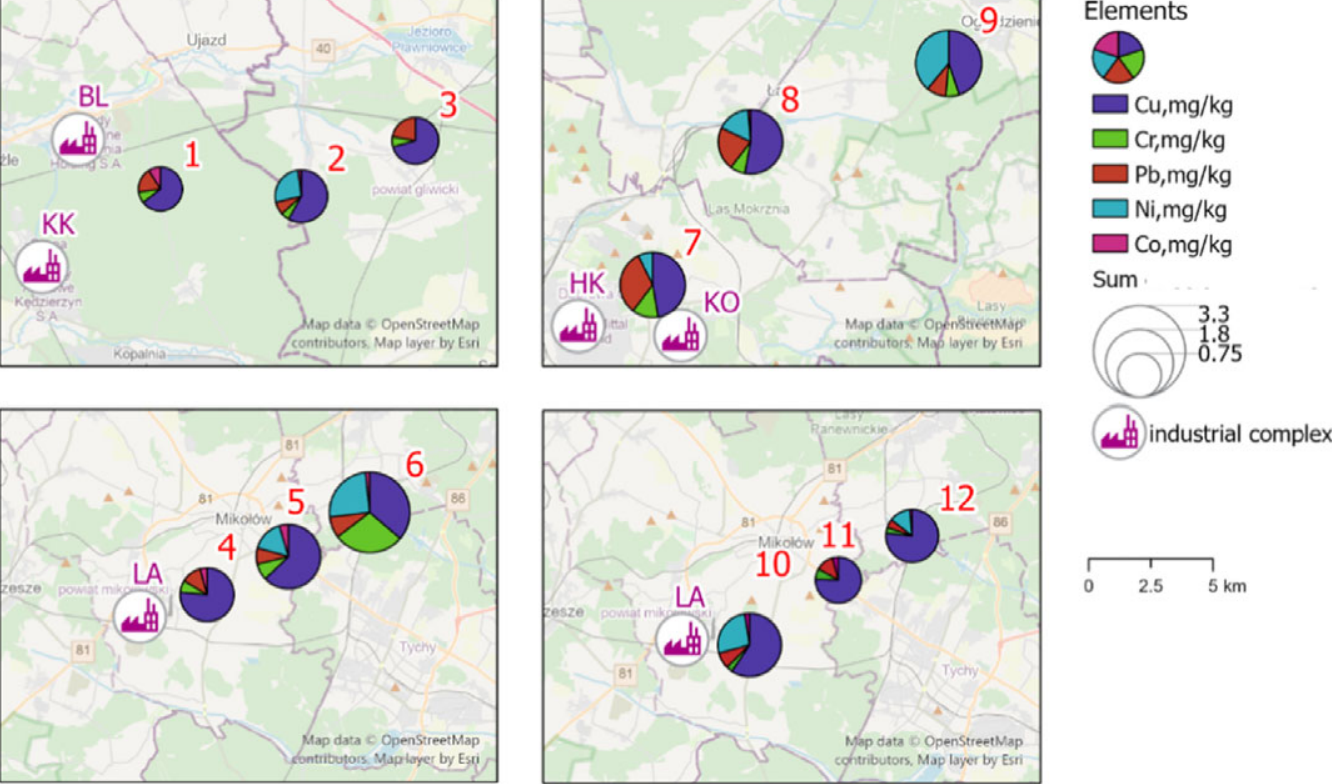

Figure 2 Accumulation of $\mathrm{Cu}, \mathrm{Cr}, \mathrm{Pb}, \mathrm{Ni}$, and $\mathrm{Co}$ in pine needles formed in 2012 (samples no. 1-9) and 2013 (samples no. 10-12) in areas near different factories, i.e., Petrochemia-Blachownia (BL) and nitrogen factories (KK), Łaziska Power Plant (LA), coking plant Przyjaźń (KO), and the steel factory Huta Katowice (HK).
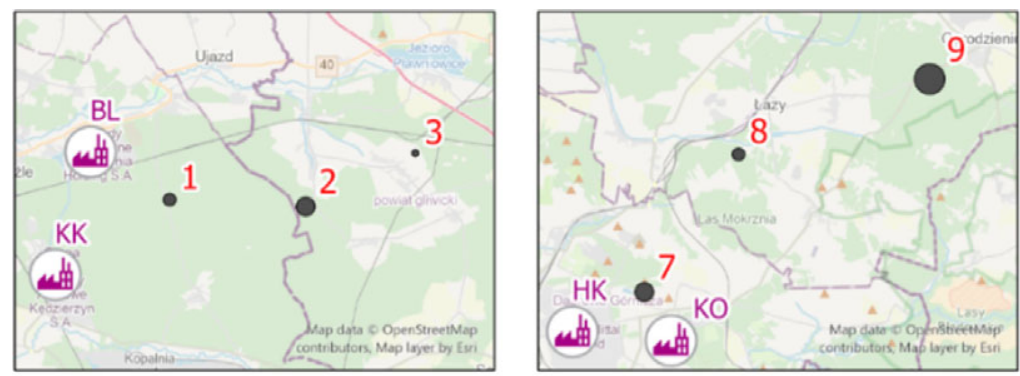

\section{$\mathrm{Zn}, \mathrm{mg} / \mathrm{kg}$}

- $\leq 4.5$

- $\leq 8$

- $\leq 12$

$\leq 14$

ifi industrial complex
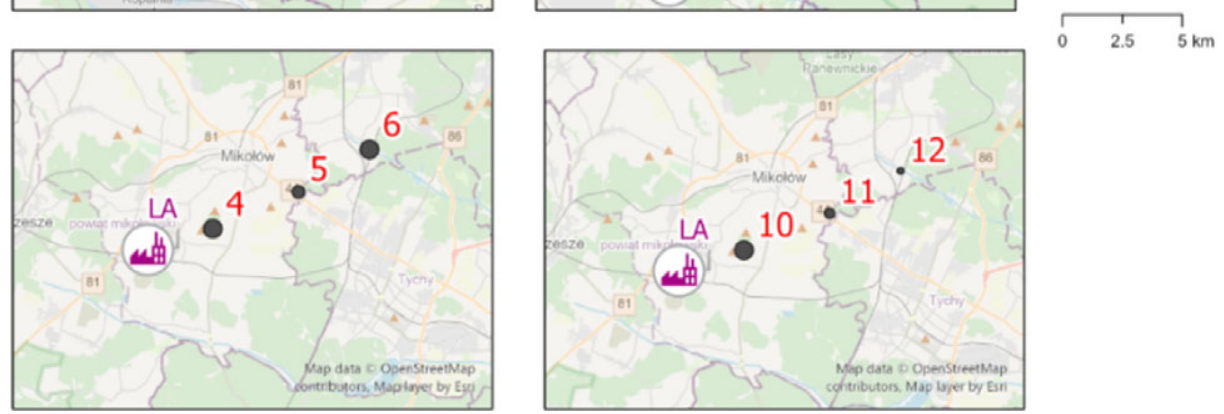

Figure 3 Accumulation of $\mathrm{Zn}$ in pine needles formed in 2012 (samples no. 1-9) and in 2013 (samples no. 10-12) in areas near different factories, i.e., Petrochemia-Blachownia (BL) and nitrogen factories (KK), Laziska Power Plant (LA), coking plant Przyjaźń (KO), and the steel factory Huta Katowice (HK). 
Table 2 Radiocarbon concentration and trace elements accumulation in annual pine needles collected in 2013 in three cities of Opole and six cities in Silesia Voivodeship. Standard deviation for trace elements was always $5 \%$ or lower. Values below the detection limit are marked as "*". The reference value of BHVO-2 was adopted from Chauvel et al. (2010). LD is the limit of detection, a. Replicate corresponds to a re-run of the same sample solution; b. Duplicate corresponds to the analyses of two different aliquots from the same sample. We determined minimum, maximum, average, median, and standard deviations for all samples.

\begin{tabular}{|c|c|c|c|c|c|c|c|c|c|c|c|c|c|c|c|c|}
\hline Sample & Site & $\begin{array}{c}\text { Year of } \\
\text { needles } \\
\text { formation }\end{array}$ & Sampling & Lab code & $\Delta^{14} \mathrm{C}$ & $u\left(\Delta^{14} C\right)$ & $\begin{array}{c}\mathrm{Cr} \\
\mathrm{mg} / \\
\mathrm{kg}\end{array}$ & $\begin{array}{c}\mathrm{Co} \\
\mathrm{mg} / \\
\mathrm{kg}\end{array}$ & $\begin{array}{c}\mathrm{Ni} \\
\mathrm{mg} / \\
\mathrm{kg}\end{array}$ & $\begin{array}{c}\mathrm{Cu} \\
\mathrm{mg} / \\
\mathrm{kg}\end{array}$ & $\mathrm{mg} / \mathrm{kg}$ & $\begin{array}{c}\mathrm{Rb} \\
\mathrm{mg} / \\
\mathrm{kg}\end{array}$ & $\begin{array}{c}\mathrm{Sr} \\
\mathrm{mg} / \\
\mathrm{kg}\end{array}$ & $\begin{array}{c}\mathrm{Ba} \\
\mathrm{mg} / \\
\mathrm{kg}\end{array}$ & $\mathrm{mg} / \mathrm{kg}$ & $\mathrm{mg} / \mathrm{kg}$ \\
\hline 1 & Sławięcice & 2012 & \multirow[t]{9}{*}{ Jan. 13} & KK_5_2012 & 103.49 & 0.65 & 0.063 & 0.068 & $*$ & 0.49 & 7.3 & 1.5 & 2.72 & 3.47 & 0.022 & 0.139 \\
\hline 2 & Rudziniec & 2012 & & KK_10_2012 & 103.37 & 0.65 & 0.056 & 0.023 & 0.29 & 0.63 & 8.4 & 1.8 & 1.44 & 1.79 & 0.031 & 0.086 \\
\hline 3 & Rudno & 2012 & & KK_15_2012 & 102.95 & 0.65 & 0.06 & 0.005 & * & 0.6 & 4.3 & 0.5 & 0.24 & 0.27 & 0.064 & 0.188 \\
\hline 4 & Wyry & 2012 & & LA_5_2012 & 103.36 & 0.51 & 0.082 & 0.048 & $*$ & 0.87 & 11.1 & 2.2 & 1.78 & 0.7 & 0.016 & 0.138 \\
\hline 5 & Mikołów & 2012 & & LA_10_2012 & 103.47 & 0.81 & 0.136 & 0.075 & 0.26 & 1.02 & 7 & 0.6 & 1.72 & 1.76 & 0.05 & 0.132 \\
\hline 6 & Podlesie & 2012 & & LA_15_2012 & 102.44 & 0.52 & 0.719 & 0.042 & 0.64 & 0.92 & 8.5 & 1.8 & 4.41 & 4.41 & 0.113 & 0.216 \\
\hline 7 & Dąbrowa G. & 2012 & & HK_5_2012 & 102.81 & 0.84 & 0.214 & 0.016 & 0.12 & 0.78 & 10.4 & 1 & 0.97 & 0.5 & 0.035 & 0.534 \\
\hline 8 & Łazy & 2012 & & HK_10_2012 & 102.98 & 0.63 & 0.123 & 0.021 & 0.27 & 0.86 & 6.4 & 1.7 & 0.41 & 0.36 & 0.029 & 0.353 \\
\hline 9 & Ogrodzieniec & 2012 & & HK_15_2012 & 101.7 & 0.62 & 0.113 & 0.014 & 0.66 & 0.76 & 14 & 4.5 & 0.77 & 1.05 & 0.049 & 0.162 \\
\hline 10 & Wyry & 2013 & \multirow[t]{3}{*}{ Sept.2013 } & LA_5_2013 & 103.69 & 0.52 & 0.058 & 0.046 & 0.474 & 1.058 & 8.977 & 2.327 & 6.113 & 1.393 & 0.027 & 0.145 \\
\hline 11 & Mikołów & 2013 & & LA_10_2013 & 103.29 & 0.78 & 0.071 & 0.04 & $*$ & 0.705 & 7.57 & 0.524 & 0.778 & 0.736 & 0.016 & 0.117 \\
\hline \multirow[t]{2}{*}{12} & Podlesie & 2013 & & LA_15_2013 & 104.92 & 0.59 & 0.045 & 0.018 & 0.159 & 0.932 & 3.942 & 1.196 & 2.025 & 2.104 & 0.016 & 0.064 \\
\hline & & & \multicolumn{4}{|l|}{ BHVO-2 } & 28 & 45 & 119 & 127 & 103 & 9-Jan & 396 & 131 & 37.5 & Jan-54 \\
\hline
\end{tabular}




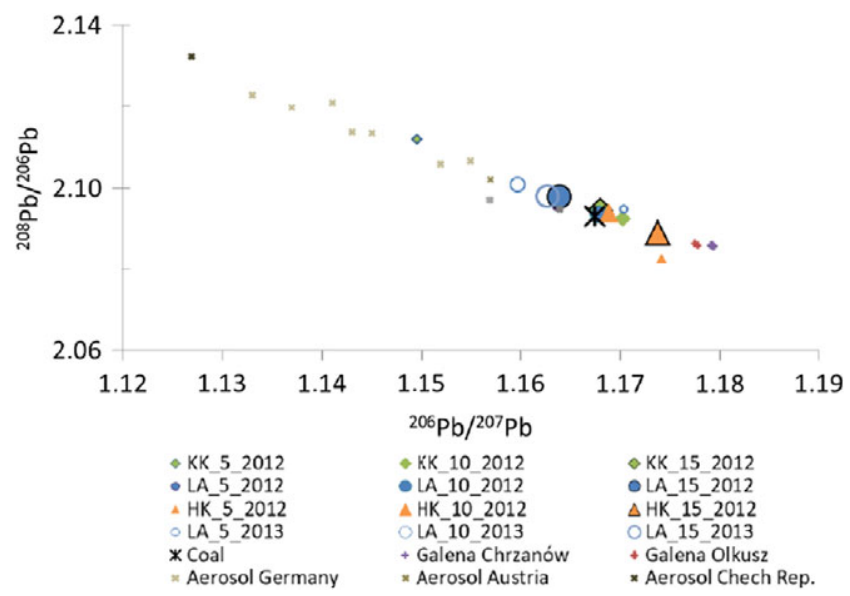

Figure 4 Variation in ${ }^{208} \mathrm{~Pb} /{ }^{206} \mathrm{~Pb}$ isotope ratio versus ${ }^{206} \mathrm{~Pb} /{ }^{207} \mathrm{~Pb}$ in pine needles (current studies), coal from Katowice, Galena from Olkusz and Chrzanów (De Vleeschouwer et al. 2009), and aerosols (after Bollhöfer and Rosman 2001).

\section{Trace Elements}

The elements $\mathrm{Ni}, \mathrm{Cr}, \mathrm{Zn}, \mathrm{Pb}, \mathrm{Co}, \mathrm{Cu}$ were mainly derived from anthropogenic sources, whereas $\mathrm{Rb}$ and $\mathrm{Sr}$ derived from the erosion of the continental crust (Bowen 1979). In the last decades, different industrial sectors and transport (leaded petrol combustion) have released large amounts of heavy metals into the atmosphere (Nriagu and Pacyna 1988), while private households have also become a significant source of air contamination. Elements absorbed by leaves are partly translocated to roots and are also leached from plant foliage, especially by acid rain. Under specific conditions, and especially with atmospheric pollution, a high proportion of trace metals may enter plant tissues.

\section{Heavy Metals}

In the province of Opolskie province nearby nitrogen factories (KK) and PetrochemiaBlachownia (BL), the $\mathrm{Cr}$ concentration in the needles was stable and low, while $\mathrm{Ni}$ was only detected in KK_10. Copper and zinc were detected in the three studied sites, with highest concentrations in $\mathrm{KK} \_10$. The $\mathrm{Pb}$ concentration differed with different distances from the factories. Higher levels were found for pines in close proximity to factories; at a distance of $10 \mathrm{~km}$, the concentrations were lower and further decreased with decreasing distance to the highway.

In the areas near the power station Laziska (Silesia Voivodeship), higher concentrations of $\mathrm{Cr}$ and $\mathrm{Ni}$ were found in pine needles from sites located farther from the factory; the larger the distance, the higher the concentrations. The $\mathrm{Cu}$ levels were similar across the area. Regarding $\mathrm{Zn}$, the highest concentration has been observed in the commune located nearest to the factory and the lowest at a distance of $7 \mathrm{~km}$; the $\mathrm{Cu}$ concentration slightly increased with increasing distance from the factory. Heavy metal accumulation in the needles differed between January and September. In September, the highest total heavy metal concentration was observed in the sampling sites closest to the factory. 
Table 3 Ratio of the $\mathrm{Pb}$ isotopic composition in annual pine needles collected in 2013 in three cities of Opole and six cities in Silesia Voivodeship. " $R$ " indicates replicate, i.e., a re-run of the same sample solution. 26 - refers to the accuracy calculated via two standard deviations. We determined minimum, maximum, average, median, and standard deviation values for all samples.

\begin{tabular}{|c|c|c|c|c|c|c|c|c|c|c|c|}
\hline & & ${ }^{208} \mathrm{~Pb}^{\prime}$ & & ${ }^{207} \mathrm{~Pb}^{\prime}$ & & ${ }^{206} \mathrm{~Pb}^{\prime}$ & & ${ }^{208} \mathrm{~Pb}^{\prime}$ & & ${ }^{207} \mathrm{~Pb} /$ & \\
\hline Sampling site & Lab code & ${ }^{204} \mathrm{~Pb}$ & $2 \sigma$ & ${ }^{204} \mathrm{~Pb}$ & $2 \sigma$ & ${ }^{204} \mathrm{~Pb}$ & $2 \sigma$ & ${ }^{206} \mathrm{~Pb}$ & $2 \sigma$ & ${ }^{206} \mathrm{~Pb}$ & $2 \sigma$ \\
\hline ław & K_5_2012 & 918 & 021 & 0729 & 0.00055 & 4149 & .00066 & 1933 & .000037 & 69902 & .00001 \\
\hline Rudzin & -10_2012 & 52 & 018 & 147 & 0067 & 45 & 57 & 314 & 0004 & 4453 & 00012 \\
\hline Rudno & 012 & 2091 & 17 & 909 & 00067 & 392 & 4 & 404 & 00047 & 6135 & 0001 \\
\hline Wyry & 12 & 0707 & 9 & & 1 & 53 & 3 & 21 & 36 & 934 & 0001 \\
\hline Mik & & 34 & 5 & 861 & 4 & 22 & & 03 & 18 & 6269 & 0001 \\
\hline $\operatorname{Pod}$ & & 71 & 7 & & & & & 578 & 36 & 59124 & 0.00001 \\
\hline $\begin{array}{l}\text { Dąbr } \\
\text { Gó1 }\end{array}$ & HK_5_2012 & 38.2213 & 0.0021 & 15.63187 & 0.00069 & 18.35484 & 0.00069 & 2.082357 & 0.000045 & 0.851657 & 0.000012 \\
\hline $\begin{array}{l}\text { Dąbrowa } \\
\text { Górnicza }^{R}\end{array}$ & 2012 & 38.2223 & 0.0023 & 15.63192 & 0.00082 & 18.35431 & 0.00079 & 2.082446 & 0.000054 & 0.851674 & 0.00001 \\
\hline Łazy & & & & & & & & 607 & 55 & 516 & 0.000015 \\
\hline Ogrod & HK_15_2012 & 38.3651 & 0.0017 & 15.64687 & 0.00072 & 18.36692 & 0.00077 & 2.088815 & 0.000043 & 0.851909 & 0.000013 \\
\hline Wyry & LA_5_2013 & 38.3067 & 0.0021 & 15.6264 & 0.00078 & 18.2894 & 0.001 & 2.094511 & 0.000045 & 0.854405 & 0.000013 \\
\hline Mikołów & LA_10_2013 & 38.036 & 0.0021 & 15.6114 & 0.001 & 18.1057 & 0.001 & 2.100799 & 0.000042 & 0.862237 & 0.000013 \\
\hline Podlesie & LA_15_2013 & 38.0875 & 0.0037 & 15.6147 & 0.0014 & 18.154 & 0.0016 & 2.098026 & 0.000048 & 0.860112 & 0.000021 \\
\hline
\end{tabular}


In the sites near the steel factory (HK) and the coking plant (KO) in Dąbrowa Górnicza (Silesia province), Ni levels were higher in the needles from stands further away from the factories. The opposite pattern was observed for $\mathrm{Cr}$ and $\mathrm{Pb}$. Copper concentrations were similar for all investigated sites. The highest $\mathrm{Zn}$ concentration was observed in the commune nearest to the factory and the lowest at a distance of $11 \mathrm{~km}$ from the factory, with a further slight increase up to a distance of $19 \mathrm{~km}$.

The concentrations of $\mathrm{Zn}, \mathrm{Cu}$, and $\mathrm{Pb}$ in pine needles measured in this study were lower than those obtained previously for pines growing near mining sites (Pietrzykowski et al. 2014). In a study from 2009, the average heavy metal concentrations in pine needles were as follows: $\mathrm{Zn}$ from 33 to $77 \mathrm{mg} / \mathrm{kg}$, Cu from 3.0 to $28 \mathrm{mg} / \mathrm{kg}$, and $\mathrm{Pb}$ from 0.8 to $3.2 \mathrm{mg} / \mathrm{kg}$, measured in Poland near Smolnica, Szczakowa, and Piaseczno, respectively. In another study, the concentrations of heavy metals in the needles of different pine species varied, with $\mathrm{Cu}$ ranging from 7 to $10 \mathrm{mg} / \mathrm{kg}$, Ni from 41 to $90 \mathrm{mg} / \mathrm{kg}$, and $\mathrm{Zn}$ from 42 to $119 \mathrm{mg} / \mathrm{kg}$ (Parzych et al. 2017). Previous studies have shown that the heavy metal concentrations in foliar dust differ among different regions; for example, in Spain, Aboal et al. (2004) found the following mean values: $\mathrm{Cr}: 0.235 \mathrm{mg} / \mathrm{kg}, \mathrm{Cu} 3.52 \mathrm{mg} / \mathrm{kg}, \mathrm{Ni} 3.71 \mathrm{mg} / \mathrm{kg}, \mathrm{Zn} 19.06 \mathrm{mg} / \mathrm{kg}$, $\mathrm{Pb} 0.059 \mathrm{mg} / \mathrm{kg}$. In a study in China, $\mathrm{Pb}$ ranged from 434.0 to $512.0 \mathrm{mg} / \mathrm{kg}$ (Yuan et al. 2009), while in another Chinese study, Ni ranged from 50.4 to $388.6 \mathrm{mg} / \mathrm{kg}$, Zn ranged from 162 to $2152 \mathrm{mg} / \mathrm{kg}$, and $\mathrm{Cu}$ ranged from 43 to $218 \mathrm{mg} / \mathrm{kg}$ (Yin et al. 2013). Although the toxicity of heavy metals for plants is widely known (Kabata-Pendias and Pendias 1992), the underlying mechanisms have not yet been fully elucidated (Pietrzykowski et al. 2014).

Figures 2 and 3 show the distribution of heavy metals in pine trees growing at distances of 3-19 $\mathrm{km}$ from factories; the median concentrations followed the order $\mathrm{Cr}<\mathrm{Pb}<\mathrm{Cu}<\mathrm{Zn}$, which is in agreement with previous findings from the same area (Sensuła et al. 2017). However, the industrial factor is not the only source of air contamination; household emissions and emissions by traffic are also considerably high. Some heavy metals can be transported by wind over long distances. It should be noted that the needles collected in winter (in January) had been formed in the spring of the previous year, accumulating elements for nearly 1 year. The samples collected in September consisted of young needles from May in the same year.

\section{Lead Isotopes}

The study area is characterized by spatial variations in the $\mathrm{Pb}$ isotopic composition of the needles (Figure 3, Tables 2 and 3). The ${ }^{208} \mathrm{~Pb} /{ }^{206} \mathrm{~Pb}$ ratio ranged from 2.08 to 2.11 and the ${ }^{206} \mathrm{~Pb} /{ }^{207} \mathrm{~Pb}$ ratio between 1.15 and 1.17 . The heterogeneity of $\mathrm{Pb}$ isotope ratio indicates that there are different sources affecting the $\mathrm{Pb}$ isotopic composition of pine needles (Figures 4-6). The samples are aligned along a linear trend that may be interpreted by a mixing line between different anthropogenic Pb sources (e.g., Bollhöfer and Rosman 2001; Doucet and Carignan 2001; Cloquet et al. 2006). The three main sources of $\mathrm{Pb}$ are related to the exploitation of galena ores, coal burning, and aerosols. In addition to industrial activities, a significant part of the pollution derived from coal combustion is probably due to low emissions by private households and coal burning for heating. The $\mathrm{Pb}$ isotopic composition of the atmosphere in Central Europe has been measured via aerosol samplers (Bollhöfer and Rosman 2001), and the results for Eastern Europe suggest a mix of alkyllead compounds from different sources, mainly related to industrial activities and coal 


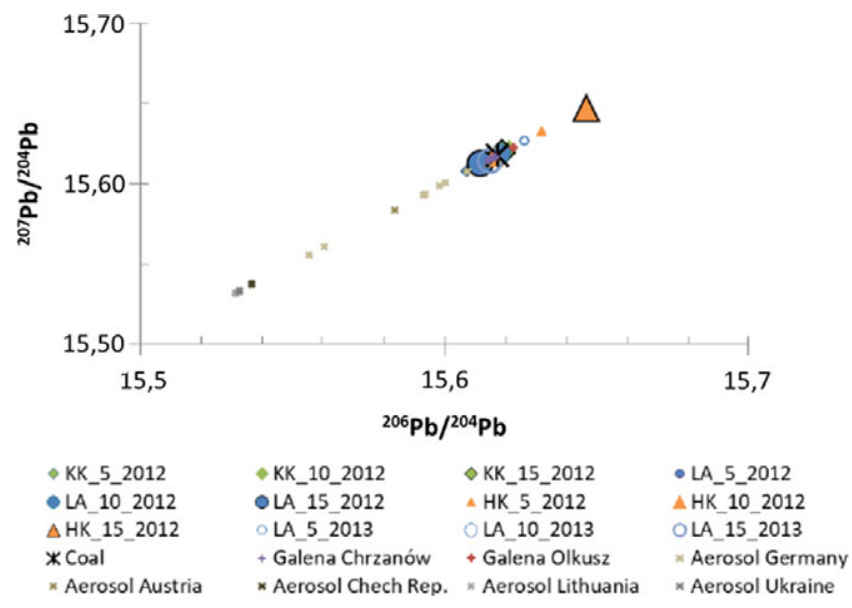

Figure 5 Variation in ${ }^{207} \mathrm{~Pb} /{ }^{204} \mathrm{~Pb}$ isotope ratio versus ${ }^{206} \mathrm{~Pb} /{ }^{204} \mathrm{~Pb}$ in pine needles (current studies), coal from Katowice, Galena from Olkusz and Chrzanów (De Vleeschouwer et al. 2009) aerosols (after Bollhöfer and Rosman 2001).
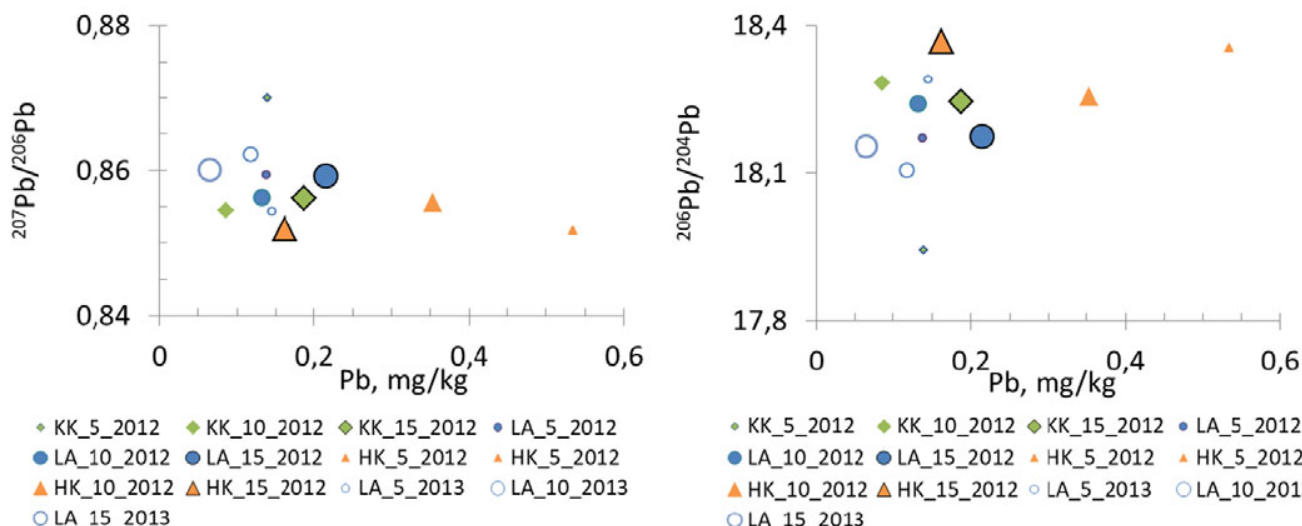

- KK_5_2012 KK_10_2012 $\diamond$ KK_15_2012 - LA 5 2012

- LA_10_2012 OLA_15_2012 A HK_5_2012 A HK_5_2012

A HK_10_2012 $\triangle$ HK_15_2012 LA_5_2013 OLA_10_2013

OLA_15_2013
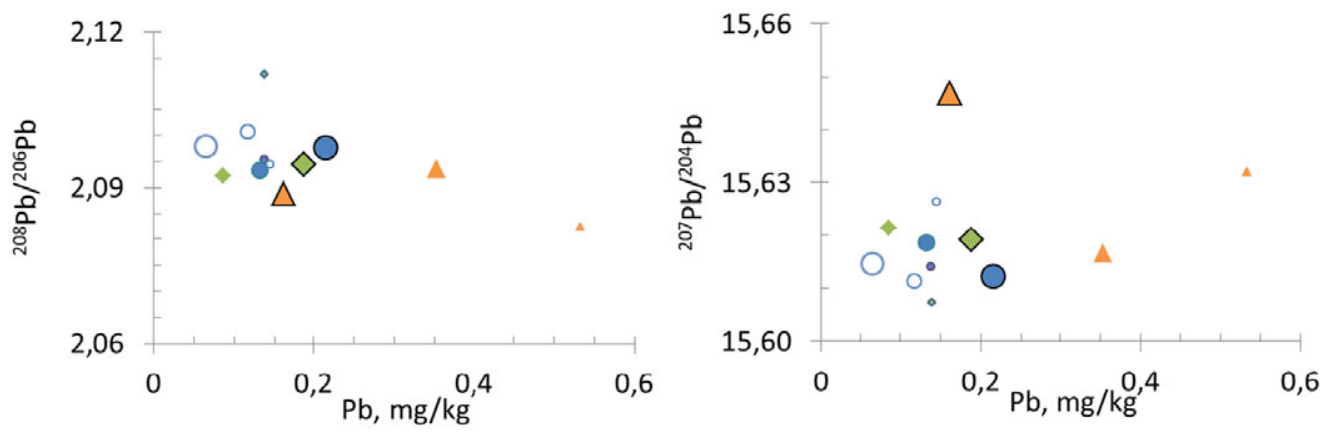

$\begin{array}{lll}- \text { KK_5_2012 } & \text { KK_10_2012 } & \diamond \text { KK_15_2012 } \\ - \text { LA_5_2012 } & \text { LA_10_2012 } & \text { OLA_15_2012 } \\ \text { A HK_5_2012 } & \text { A HK_5_2012 } & \text { A HK_10_2012 } \\ \text { A HK_15_2012 } & \text { LA_5_2013 } & \text { LA_10_2013 } \\ \text { OLA_15_2013 } & \end{array}$

- KK_5_2012

- KK_10_2012 $\diamond$ KK_15_2012

- LA 5 2012

- LA_10_2012

- LA_15_2012

A HK_5_2012

4 HK_5_2012

A HK_10_2012

$\triangle H K \_15 \_2012$

- LA_5_2013

O LA_10_2013

Figure 6 Distribution of $\mathrm{Pb}$ isotopic ratio in comparison with lead concentration. 
burning (Bollhöfer and Rosman 2001). Lead from the industrial sector, associated with coal and steel plants, was enriched in ${ }^{206} \mathrm{~Pb}$ and ${ }^{207} \mathrm{~Pb}$ compared to ${ }^{204} \mathrm{~Pb}$. Depletion in ${ }^{206} \mathrm{~Pb}$ and ${ }^{207} \mathrm{~Pb}$ compared to ${ }^{204} \mathrm{~Pb}$ (i.e., ${ }^{206} \mathrm{~Pb} /{ }^{204} \mathrm{~Pb}<17.7$ ), ${ }^{207} \mathrm{~Pb} /{ }^{204} \mathrm{~Pb}<15.58$, respectively) corresponds to the European gasoline lead origin. The end-member with a low ${ }^{206} \mathrm{~Pb} /{ }^{207} \mathrm{~Pb}$ isotope ratio is most probably influenced by traffic (Bollhöfer and Rosman 2001).

Although lead gasoline was banned in the year 2000 in Poland, plants may still accumulate lead from other sources. Analysis of the lead isotopic ratio ${ }^{208} \mathrm{~Pb} /{ }^{206} \mathrm{~Pb}$ versus ${ }^{206} \mathrm{~Pb} /{ }^{207} \mathrm{~Pb}$ showed that local coal and galena are the two main sources of lead, although previous $\mathrm{Pb}$ pollution cannot be excluded. Lead can remain in the soil over several years and can be taken up by plants via the roots. However, Dalenberg and van Driel (1990) have calculated that 73 to $95 \%$ of the total ${ }^{210} \mathrm{~Pb}$ content of field crops are derived from aerial deposition on leaf surfaces.

\section{CONCLUSIONS}

We determined radiocarbon, trace element accumulation, and $\mathrm{Pb}$ isotope ratios in pine needles collected in a heavily industrialized area of Poland to evaluate the degree of air contamination. Most of the elements were derived from anthropogenic activities. The temporal and spatial variations were evident. All sampling sites are characterized by high levels of radiocarbon. Also high level of zinc and copper, and lead was detected in pine needles. The variation in the radiocarbon indicates a mix between different sources of ${ }^{14} \mathrm{C}$, also lead isotopic composition indicates a mix between different sources $\mathrm{Pb}$, respectively. Industrial activity, private households, and transport are a source of atmospheric contamination in the provinces of Opolskie and Silesia.

\section{ACKNOWLEDGMENTS}

The authors express their sincere gratitude to everyone who contributed to this study, particularly Joel Ottan from the University of Liège and Nadine Mattielli from Laboratoire G-Time, Université Libre de Bruxelles, Belgium. This work was supported by National Science Center, Poland [grant number DEC-2011/03/D/ST10/05251], the Ministry of Science and Higher Education [grant number BKM-507/RIF/2013, BKM-509/RIF/2014 and BKM-513/RIF/2015], the rector's grant in the area of research and development, Silesian University of Technology [grant number 14/990/RGJ19/0117, PI Barbara Sensuła], WBI 2017-2019; PI: B. Sensuła, N. Fagel.

\section{REFERENCES}

Aboal JR, Fernández JA, Carballeira A. 2004. Oak leaves and pine needles as biomonitors of airborne trace elements pollution. Environmental and Experimental Botany 51(3):215-225.

Adriano DC. 2001. Trace elements in terrestrial environments: biogeochemistry, bioavailability and risks of metals. 2nd edition. Springer, USA.

Alfani AG, Maisto G, Iovieno P, Rutigliano FA, Bartoli G. 1996. Leaf contamination by atmospheric pollutants as assessed by elemental analysis of leaf tissue, leaf surface deposit and soil. Journal of Plant Physiology 148(1-2):243-248.

Baumann K, Rumpelt A, Schneider BU, Marschner P, Hüttl, RF. 2006. Seedling biomass and element content of Pinus sylvestris and Pinus nigra grown in sandy substrates with lignite. Geoderma 136:73-78.

Białobok S. 1976. Outline of physiology of Scots pine (Zarys fizjologii sosny zwyczajnej). Springfield, VA: Published for the U.S. Dept. of Agriculture and the [U.S.] National Science Foundation by the Foreign Scientific Publications Dept. of the [Polish] National Center for Scientific Technical.

Białobok S, Boratyński A, Bugała W. 1993. Biologia sosny zwyczajnej. Kórnik, Poznań: Sorus.

Bollhöfer A, Rosman KJR. 2001. Isotopic source signatures for atmospheric lead: the Northern Hemisphere. Geochim. Cosmochim Acta 65: 1727-1740. 
Bowen HJM. 1979. Environmental chemistry of the elements. New York: Academic Press.

Cloquet C, Carignan J, Libourel G. 2006. Isotopic composition of $\mathrm{Zn}$ and $\mathrm{Pb}$ atmospheric depositions in an urban/periurban area of northeastern France. Sci. Environ. Technol. 40(21):6594-6600.

Dalenberg JW, van Driel W. 1990. Contribution of atmospheric deposition to heavy metal concentration in field crops. Netherlands J. Agric. Sci. 38:367.

Dawson TE, Mambelli S, Plamboeck AH, Templer $\mathrm{PH}, \mathrm{Tu}$ KP. 2002. Stable isotopes in plant ecology. Annual Review of Ecology and Systematics 33(1):507-559.

De Vleeschouwer F, Fagel N, Cheburkin A, Pazdur A, Sikorski J, Mattielli N, Renson V, Fialkiewicz B, Piotrowska N, Le Roux G. 2009. Anthropogenic impacts in North Poland over the last 1300 years-a record of $\mathrm{Pb}, \mathrm{Zn}, \mathrm{Cu}, \mathrm{Ni}$ and $\mathrm{S}$ in an ombrotrophic peat bog. Science of the Total Environment 407(21):5674-5684.

De Vleeschouwer F, Gérard L, Goormaghtigh C, Mattielli N, Le Roux G, Fagel N, 2007. Atmospheric lead and heavy metal pollution records from a Belgian peat bog spanning the last two millenia: human impact on a regional to global scale. Science of the Total Environment 377(2-3):282-295.

Dmuchowski W, Bytnerowicz A. 1995. Monitoring environmental pollution in Poland by chemical analysis of Scots pine (Pinus sylvestris L.) needles. Environ. Pollut. 87:87-104.

Doucet FJ, Caringan J. 2001. Atmospheric Pb isotopic composition and trace metal concentration as revealed by epiphytic lichens: an investigation related to two altitudinal sections in Eastern France. Atmospheric Environment 35:3681-3690.

Hammer S, Levin I. 2017. Monthly mean atmospheric ${ }^{14} \mathrm{CO}_{2}$ at Jungfraujochand Schauinsland from 1986 to 2016 [data set, www document]. University Library Heidelberg. https://doi.org/10.11588/data/10100.

Jelaska LS, Blanusa M, Durbesic P, Jelaska SD. 2007. Heavy metal concentrations in ground beetles, leaf litter, and soil of a forest ecosystem. Ecotoxicology and Environmental Safety 66:74-81.

Kabata-Pendias A, Pendias H. 1992. Trace elements in soil and plants. 2nd ed. Boca Raton, London: CRC Press.

Keeling CD. 1979. The Suess effect: ${ }^{13}$ Carbon${ }^{14}$ Carbon interrelations. Environment International 2(4-6):229-300.

Kuznetsova T, Mandre M, Klõseiko J, Pärn H. 2010. A comparison of the growth of Scots pine (Pinus sylvestris L.) in a reclaimed oil shale post-mining area and in a Calluna site in Estonia. Environ. Monit. Assess. 166:257-65.

Łukaszewski Z, Siwecki R, Opydo J, Zembrzuski W. 1988. The effect of industrial pollution on zinc, cadmium and copper concentration in the xylem rings of Scot's pine (Pinus sylvestris L.) and in the soil. Trees 2:1-6.

Malik I, Danek M, Marchwińska-Wyrwał E, Danek T, Wistuba M, Krąiec M. 2012. Scots pine (Pinus sylvestris L.) growth suppression and adverse effects on human health due to air pollution in the Upper Silesian Industrial District (USID), southern Poland. Water, Air and Soil Pollution 223:3345-3364.

Mook W, van der Plicht, J. 1999. Reporting ${ }^{14} \mathrm{C}$ activities and concentrations. Radiocarbon 41(3):227-239.

Norman T. 1999. Damage in the Regional State Forests in Katowice caused pollution by industry, mining activities and infrastructure development in the region. Szkody w lasach państwowych Regionalnej Lasów Państwowych w Katowicach wywołane imisjami przemysłowymi, działalnością górniczą oraz rozwojem infrastruktury region (in Polish). Problemy Ekologii 5:169-176.

Nriagu JO, Pacyna JM. 1988. Quantitative assessment of worldwide contamination of air, water and soil by trace metals. Nature 333:134-139.

Parzych A, Mochnacky S, Sobisz Z, Kurhaluk N, Polláková N. 2017. Accumulation of heavy metals in needles and bark of Pinus species. Folia Forestalia Polonica 59:34-44.

Pazdur A, Fogtman M, Michczyński A, Pawlyta J. 2013. Precision of ${ }^{14} \mathrm{C}$ dating in Gliwice radiocarbonoratory. FIRI Programme. Geochronometria 22:27-40.

Pietrzykowski M, Socha J, van Doornd N. 2014. Linking heavy metal bioavailability $(\mathrm{Cd}, \mathrm{Cu}$, $\mathrm{Zn}$ and $\mathrm{Pb}$ ) in Scots pine needles to soil properties in reclaimed mine areas. Science of the Total Environment 470-477:501-510.

Pomierny S, Ciepał R. 2004. Assessment of the impact of many years of industrial emissions on the soil and plants within the protection zone "Huta Katowice". Ocena wieloletniego oddziaływania emisji przemysłowych na gleby i rośliny w granicach strefy ochronnej „Huty Katowice”. Acta Agrophysica 4(2):475-489. In Polish.

Prasad MNV, Sajwan KS, Naidu R. 2006. Trace elements in the environment: biogeochemistry, biotechnology, and bioremediation. USA: CRS Press.

Przybysz A, Sæbø A, Hanslin HM, Gawroński SW. 2014. Accumulation of particulate matter and trace elements on vegetation as affected by pollution level, rainfall and the passage of time. Science of the Total Environment 481: 360-369.

Rovinsky FY, Burtseva LV, Chicheva TV. 1993. Heavy metals in the vegetationas indicators for the environmental pollution in the area of the former USSR. In: Markert B, editor. Plants as biomonitors, indicators for heavy metals in the terrestrial environment, VCH. Weinheim. p. 507-514. 
Rozanski K. 1991. Consultants' group meeting on ${ }^{14} \mathrm{C}$ reference materials for radiocarbon laboratories. February 18-20, 1991, Vienna, Austria. IAEA Internal Report. Vienna: International Atomic Energy Agency.

Savard MM. 2010. Tree-ring stable isotopes and historical perspectives on pollution-an overview. Environ. Pollut. 158: 2007-2013.

Sensuła B. 2015. Spatial and short-temporal variability of delta C-13 and delta N-15 and water-use efficiency in pine needles of the three forests along the most industrialized part of Poland. Water Air and Soil Pollution 226(11), article 362.

Sensuła B. 2016. The impact of climate, sulfur dioxide, and industrial dust on delta o-18 and delta c-13 in glucose from pine tree rings growing in an industrialized area in the southern part of Poland. Water Air and Soil Pollution 227(4), article 106.

Sensuła B, Opala M, Wilczynski S, Pawelczyk S. 2015b. Long- and short-term incremental response of Pinus sylvestris L. from industrial area nearby steelworks in Silesian Upland, Poland. Dendrochronologia 36:1-12.

Sensuła B, Wilczynski S, Opala M. 2015a. Tree growth and climate relationship: dynamics of Scots pine (Pinus Sylvestris L.) growing in the near-source region of the combined heat and power plant during the development of the pro-ecological strategy in Poland. Water Air and Soil Pollution 226(7), article 220.
Sensuła B, Wilczyński S, Monin L, Allan M, Pazdur A, Fagel N. 2017. Variations of tree ring width and chemical composition of wood of pine growing in the area nearby chemical factories. Geochronometria 44:26-239.

Sensuła B, Michczyński A, Piotrowska N, Wilczyński S. 2018. Anthropogenic $\mathrm{CO}_{2}$ emission records in Scots pine growing in the most industrialized region of Poland from 1975 to 2014. Radiocarbon 60(4): 1041-1053.

Steinnes E, Grodzińska K, Szarek-Łukaszewska G, Nygárd T. 2005. Stężenie ośmiu metali śladowych w powierzchniowej warstwie gleb: porównanie między Polską i Norwegią, Chem. Inz. Ekol. 12(5-6):603-609.

Trumbore SE. 2006. Carbon respired by terrestrial ecosystems-recent progress and challenges. Global Change Biol 12:141-153.

Yin R, Wang D, Deng H, Shi R, Chen Z. 2013. Heavy metal contamination and assessment of roadside and foliar dust along the Outer-Ring Highway of Shanghai, China. J. Environ. Qual. 42:1724 1732.

Yuan Q, Dongsheng G, Weiwei S, Kangyou H. 2009. Capture of heavy metals and sulfur by foliar dust in urban Huizhou, Guangdong Province, China, Chemosphere 75(4):447-452.

Zwoliński J. 1995. Effects of emissions from non-ferrous metal works on forest environment-the role of heavy metals in forest degradation. Journal of the Forest Research Institute, Series A 809:1-86. 